\section{BOSTON MEETING}

Symposia at a glance

\section{MEETING \\ Chairmen for Boston named}
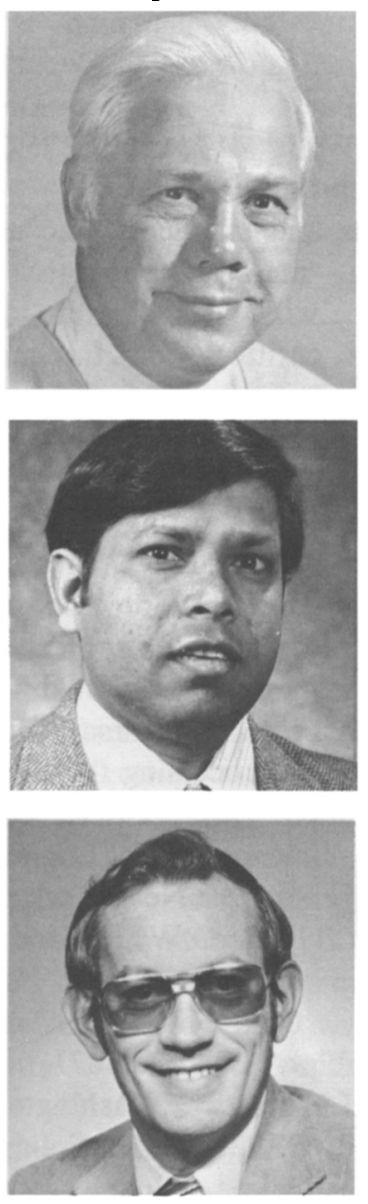

ASSOCIATE EDITORS

of Materials Letters

\title{
REFUSENIK
}

\section{USSR bars scientist from MRS meeting}

The keynote speaker of the MRSsponsored conference on phase transformations in solids, Dr. Armen Khachaturyan of the Union of Soviet Socialist Republics, has failed to receive an exit visa from his government and will not attend the meeting, which is being held in Crete.

In protest, Dr. Khachaturyan informs us in a letter whose text is furnished in the adjoining column, the eminent physicist plans to go on a hunger strike during the term of the meeting, which is the five-day period June 27 - July 1.

The letter was received as a photo copy from microfilm, bearing a West German postmark. It is not a hoax. Prof. J.W. Morris of the University of California at Berkeley, a colleague of Dr. Khachaturyan when the Soviet scientist studied in the United States several years ago, was able to place a telephone call to Dr. Khachaturyan and confirm that the letter is authentic.

Dr. Khachaturyan and his wife, Svetlana Semenovskaya-Khachaturyan, who was also to attend the meeting and who like her husbard did not receive an exit visa, are refuseniks - those who persist in efforts to emigrate from the Soviet Union despite official disapproval. The Khachaturyans are of Armenian and Jewish descent.

On behalf of the Society, the chairman of the phase transformation conference, Tom Tsakalakos of Rutgers, wrote to the Academy of [Continued on Page 5]

\section{$A$ Letter}

From Armen

\section{Khachaturyan}

TO the members of Organizing Committee of the International Conference on Phase Transformations in solids, Maleme, Crete, Greece

Dear colleagues,

Thank you very much for your kind invitation to attend the Conference. We are, however, deeply distressed to find out that the Soviet Academy of Science does not give us the permission to participate it. We applied for permission to the VicePresidents of the USSR Academy E.P. Velikhov and Yu.A. Ovchinaikov, but in vain. This case reflects our present situation as two year refuseniks in which we found ourselves after application to join our relatives abroad. We are deprived of opportunity to communicate with our colleagues, and cut off from all normal channels of scientific work and collaboration. But the most distressing situation is with our son Karen Khachaturyan who was expelled from the [Continued on Page 5] 


\section{REFUSENIK}

\section{[Continued from Page 1]}

Sciences of the USSR. Noting that the inability of $\mathrm{Dr}$. Khachaturyan to receive papers from his government allowing him to attend created numerous problems for conference organizers, he went on to state:

You must recognize that problems such as this have a potentially adverse effect on all Soviet scientists. If international organizing committees must question whether your government will permit the attendance of a scientist of the eminence of Khachaturyan in response to an invitation that honors him and, by association, all Soviet science, then those committees will, necessarily, also question whether it is worthwhile to expend the effort to involve any Soviet scientists in international technical conferences.

Dr. Khachaturyan is indeed eminent in his field. His theoretical work on phase transformations in crystalline solids has challenged prevailing views and stimulated fresh experimental investigations. His innovative approaches to the theory of alloy decomposition and premartensitic transformation phenomena are receiving attention worldwide, and promise a fuller understanding of the pervasive and technologically important transformation mechanisms in concentrated solid solutions.

I share Tom Tsakalakos's indignation that Dr. Khachaturyan is denied by the Soviet government the opportunity to participate in our meeting. I am saddened by the pain which this episode reveals has been inflicted on the Khachaturyans. I wish them well, as I am sure all of my MRS colleagues do. It will be a better day when next Dr. Khachaturyan and his colleagues from throughout the scientific community can meet.

\section{Harry Leamy}

President

Materials Research Society

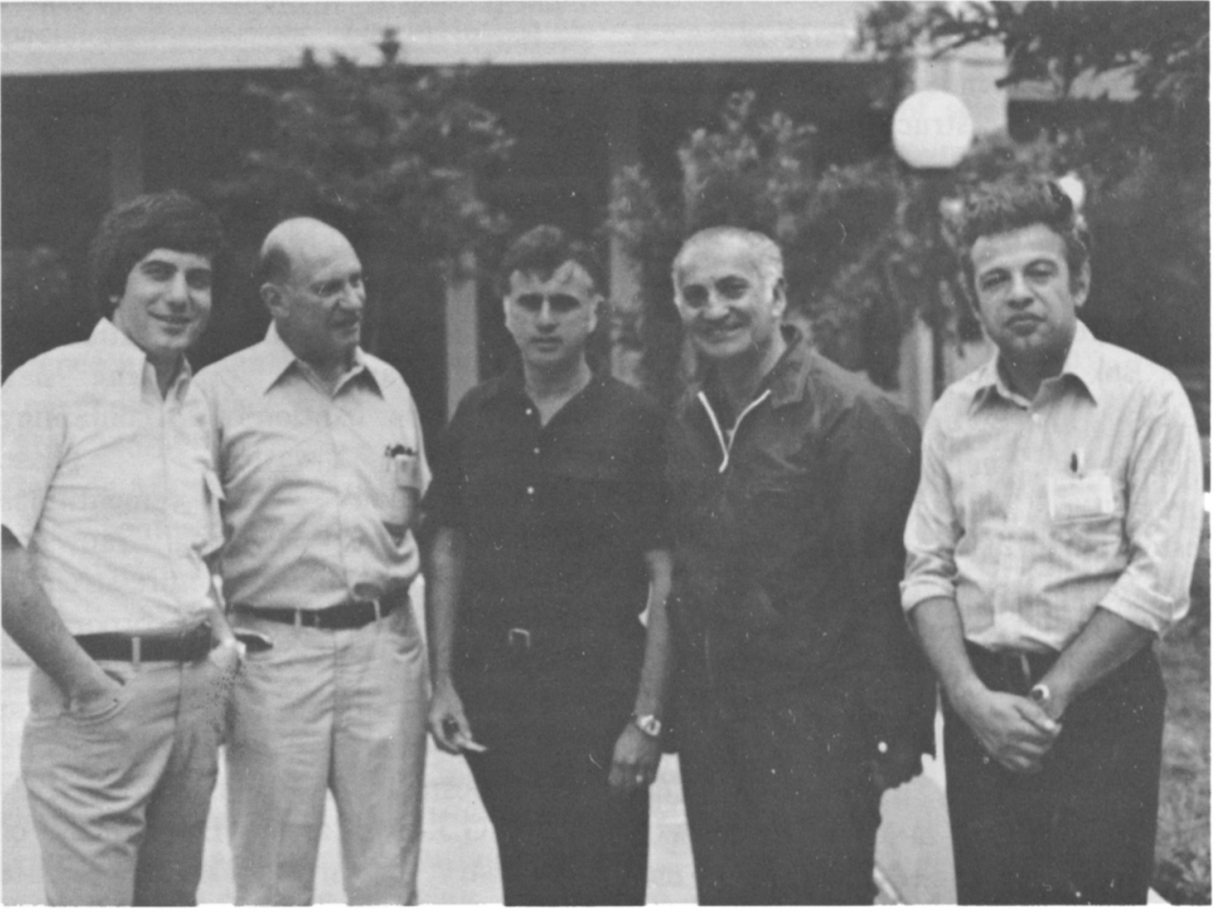

ARMEN KHACHATURYAN in happier days at the International Meeting on Modulated Structures; Hawaii, March 1979. Khachaturyan is at the extreme right. Others in the group are, from left to right: T. Tsakalakos, Rutgers University, L. Zwell, International Centre of Powder Diffraction Data, J. Cohen, Northwestern University, and S. Weissmann, Rutgers University.

\section{LETTER}

\section{[Continued from Page 1]}

Moscow University for application and lost his right to continue his education and have a decent job. The details you may have seen from the enclosed letter to participants of the Conference, which we wrote together with our colleaguesrefuseniks Prof. Dr. E. Nadgornyi and Prof. Dr. L. Ozernoy. [This letter will be read to conference participants in Crete.] They joined us in our decision to go on the hunger- strike during all the working time of the Conference lemphasis in the original] as a protest against the refusal of the USSR Academy of Sciences to allow us to attend the Conference and against the refusal of the Soviet authorities to give us exit visas.

\section{Faithfully yours}

[Signed]

Armen Khachaturyan

Svetlana Semenovskaya-

Khachaturyan

May 5, 1983 